\title{
Convention on Biological Diversity
}

7 be Contracting Parties, concious of the intrinsic value of biological diversity and of the ecological, genetic, social, 1 economic, scientific, educational, cultural, recreational and aesthetic values of biological diversity and its components,

Conscious also of the importance of biological diversity for evolution and for maintaining life sustaining systems of the biosphere,

Affirming that the conservation of biological diversity is a common concern of humankind,

Reaffirming that States have sovereing rights over their own biological resources,

Reaffirming also that States are responsible for conserving their biological diversity and for using their biological resources in a sustainable manner,

Concerned that biological diversity is being significantly reduced by certain human activities,

Aware of the general lack of information and knowledge regarding biological diversity and of the urgent need to develop scientific, technical and institutional capacities to provide the basic understanding upon which to plan and implement appropriate measures,

Noting that it is vital to anticipate, prevent and attac the causes of significant reduction or loss of biological diversity at source,

Noting also that where there is a threat of significant reduction or loss of biological diversity, lack of full scientific certainty should not be used as a reason for postponing measures to avoid or minimize such a threat,

Noting further that the fundamental requirement for the conservation of biological diversity in the in-situ conservation of ecosystems and natural habitats and the maintenance and recovery of viable populations of species in their natural surroundings, 
Noting further that ex-situ measures, preferably in the country of origin, also have an important hole to play,

Recognizing the close and traditional dependence of many indigenous and local communities embodying traditional lifestyles on biological resources, and the desirability of sharing equitably benefits arising from the use of traditional knowledge, innovations and practices relevant to the conservation of biological diversity and the sustainable use of its components,

Recognizing also the vital role that women play in the conservation and sustainable use of biological diversity and affirming the need for the full participation of women at all levels of policy-making and implementation for biological diversity conservation,

Stressing the importance of, and the need to promote international, regional and global cooperation among States and intergovernmental organizations and non-governmental sector for the conservation of biological diversity and the sustainable use of its components,

Acknowledging that the provision of new and additional financial resources and appropriate access to relevant technologies can be expected to make a substantial difference in the world's ability to address the loss of biological diversity,

Acknowledging further that special provision is required to meet the needs of developing countries, including the provision of new and additional financial resources and appropriate access to relevant technologies,

Noting in this regard the special conditions of the least developed countries and small island States,

Acknowledging that substancial investments are required to conserve biological diversity and that there is the expectation of a broad range of environmental, economicand social benefits from those investments,

Recognizing that economical and social development and poverty eradication are the first and overriding priorities of developing contries,

Aware that conservation and sustainable use of biological diversity is of critical importance for meeting the food, health and other needs of the growing world populations, for which purpose access to and sharing of both geneticresources and technologies are essential,

Noting that, ultimately, the conservation and sustainable use of 
biological diversity will strengthen friendly relations among States and contribute to peace for humankind,

Desiring to enhance and complement existing international arrangements for the conservation of biological diversity and sustainable use of its components, and

Determined to conserve and sustainably use of biological diversity for the benefit of present and future generations,

Have agreed as follows:

\section{Article 1}

\section{Objectipes}

The objectives of this Convention, to be pursued in accordance with its relevant provisions, are the conservation of biological diversity, the sustainable use of its components and the fair and equitable sharing of the benefits arising out of the utilization of geneticresources, including by appropriate access to geneticresources and by appropriate transfer of relevant technologies, taking into account all rights over those resources and to technologies, and by appropriate funding.

\section{Article 2}

\section{Use of Terms}

For the purposes of this Convention:

"Biological diversity" means the variability among living organisms from all sources including, inter alia, terrestrial, marine and other aquaticecosystems and the ecological complexes of which they are part; this includes diversity within species, between species and of ecosystems.

"Biological resources" includes geneticresources, organisms or parts thereof, populations, or any other bioticcomponent of ecosystems with actual or potential use or value for humanity.

"Biotechnology " means any technological application that uses bilogical systems, living organisms, or derivatives thereof, to make or modify products or processes for specific use.

"Country of origin of genetic resources" means the country which possesses those genetic resources in in-situ conditions. "Country providing geneticresources" means the country supplying genetic 
resources collected from in-situ sources, including populations of both wild and domesticated species, or taken from ex-situ sources, which may or may not have originated in that country.

"Domesticated or cultipated species" means species in which the evolutionary process has been influenced by humans to meet their needs.

"Ecosystem " means a dynamiccomplex of plant, animal and micro-organism communities and their non-living environment interacting as a functional unit.

"Exc-situ conservation" means the conservation of components of biological diversity outside their natural habitats.

" Geneticmaterial" means any material of plant, animal, microbial or other origin containing functional units of heredity.

" Geneticresources " means geneticmaterial of actual or potential value.

" Habitat" means the place or type of site where an organism or population naturally occurs.

"In-situ conditions" means conditions where geneticresources exist within ecosystems and natural habitats, and, in the case of domesticated or cultivated species, in the surrounding where they have developed their distinctive properties.

"In-situ conserpation" means the conservation of ecosystems and natural habitats and the maintenance and recovery of viable populations of species in their natural surroundings and, in the case of domesticated or cultivated species, in the surroundings where they have developed their distinctive properties.

"Protected area " means a geographically defined area which is designated or regulated and managed to achieve specific conservation objectives.

"Regional economic integration organization means an organization constituted by sovereing States of a given region, to which its member States have transferred competence in respect of matters governed by this Convention and which has been duly authorized, in accordance with its internal procedures, to sign, ratify, accept, approve or accede to it. "Sustainable use" means the use of components of bilogical diversity in a way and at a rate that does not lead to the long-term decline of biological diversity, thereby maintaining its 
potential to meet the needs and aspirations of present and future generations.

"Technology" includes biotechnology.

\section{Article 3}

\section{Principle}

States have, in accordance with the Charter of the United Nations and the principles of international law, the sovereign right to exploit their own resources pursuant to their own environmental policies, and the responsibility to ensure that activities within their jurisdiction or control do not cause damage to the environment of other States or of areas beyond the limits of national jurisdiction.

\section{Article 4}

\section{Jurisdictional Scope}

Subject to the rights of other States, and except as otherwise expressly provided in this Convention, the provisions of this Convention apply, in relation to each Contracting Party:

(a) In the case of components of biological diversity, in areas within the limits of its national jurisdiction; and

(b) In the case of processes and activities, regardless of where their effects occur, carried out under its jurisdiction or control, within the area of its national jurisdiction or beyond the limits of national jurisdiction.

\section{Article 5}

\section{Cooperation}

Each Contracting Party shall, as far as possible and as appropriate, cooperate with other Contracting Parties, directly or, where appropriate through competent International organizations, in respect of areas beyond national jurisdiction and on other matters of mutual interest, for the conservations and sustainable use of biological diversity. 


\section{Article 6}

\section{General Measures for Conserpation and Sustainable Use}

Each Contracting Party shall, in accordance with its particular conditions and capabilities:

(a) Develop national strategies, plans or programmes for the conservation and sustainable use of biological diversity or adapt for this purpose existing strategies, plans or programmes which shall reflect, inter alia, the measures set out in this Convention relevant to the Contrating Party concerned; and

(b) Integrate, as far as possible and as appropriate, the conservation and sustainable use of biological diversity into relevant sectoral or cross-sectoral plans, programmes and policies.

\section{Article 7}

\section{Identification and Monitoring}

Each Contracting Party shall, as far as possible and as appropriate, in particular for the purposes of Articles 8 to 10:

(a) Identify components of bilogical diversity important for its conservation and sustainable use having regard to the indicative list of categories set down in Annex I;

(b) Monitor, through sampling and other techniques, the components of biological diversity identified pursuant to subparagraph (a) above, paying particular attention to those requiring urgent conservations measures and those wich offer the greatest potential for sustainable use;

(c) Identify processes and categories of activities which have or are likely to have significant adverse impacts on the conservation and sustainable use of biological diversity, and monitor their effects through sampling and other techniques; and

(d) Mainting and organize, by any mechanism data, derived from identification and monitoring activities pursuant to subparagraphs (a), (b) and above. 


\section{Article 8}

\section{In-situ Conserpation}

Each Contracting Party shall, as far as possible and as appropriate:

(a) Establish a system of protected areas or areas where special measures need to be taken to conserve biological diversity;

(b) Developed, where necessary, guidelines for the selection, establishment and mannagement or protected areas or areas where special measures need to be taken to conserve biological diversity;

(c) Regulate or manage biological resources important for the conservation of biological diversity whether within or outside protected areas, with a view to ensuring their conservation and sustainable use;

(d) Promote the protection of ecosystems, natural habitats and the maintenance of viable populations of species in natural surroundings;

(e) Promote environmentally sound and sustainable development in areas adjacent to protected areas wich a view to furthering protection of these areas;

(f) Rehabilitate and restore degraded ecosystems and promote the recovery of threatened species, inter alia, through the development and implementation of plans or other management strategies;

(g) Establish or maintain means to regulate, manage or control the risks associated with the use and release of living modified organisms resulting from biotechnology which are likely to have adverse environmental impacts that could affect the conservation and sustainable use of biological diversity, taking also into account the risks to human health;

(h) Prevent the introduction of, control or eradicate those alien species which threaten ecosystems, habitats or species;

(i) Endeavor to provide the conditions needed for compatibility between present uses and the conservation of biological diversity and the sustainable use of its components;

(j) Subject to its national legislation, respect, preserve and maintain knowledge, innovations and practices of indigenous and local communities embodying traditional lifestyles relevant for the conservations and sustainable use of biological diversity and promote their wider application with the approval and involvement of the holders of such knowledge, 
innovations and practices and encourage the equitable sharing of the benefits arising from the utilization of such knowledge, innovations and practices;

(k) Develop or maintain necessary legislation and/or other regulatory provisions for the protection of threatened species and populations;

(l) Where a significant adverse effect on biological diversity has been determined pursuant to Article 7, regulate or manage the relevant processes and categories of activities; and

(m) Cooperate in providing financial and other support for in-situ conservation outlined in subparagraphs (a) to (l) above, particularly to developing countries.

\section{Article 9 \\ Ex-situ Conserpation}

Each Contracting Party shall, as far as possible and as appropriate, and predominantly for the purpose of complementing in-situ measures:

(a) Adopt measures for the ex-situconservation of components of biological diversity, preferably in the country of origin of such components;

(b) Estabilish and maintain facilities for ex-situ conservation of and research on plants, animals and micro-organisms, preferably in the country of origin of genetic resources;

(c) Adopt measures for the recovery and rehabilitation of threatened species and for their reintroduction into their natural habitats under appropriate conditions;

(d) Regulate and manage collection of biological resources from natural habitat for ex-situ conservations purposes so as not to threaten ecosystems and in-situ populations of species, except where special temporary ex-situ measures are required under subparagraph (c) above; and

(e) Cooperate in providing financial and other support for $e x$-situ conservation outlined in subparagraphs (a) to (d) above and

in the establishment and maintenance of ex-situ conservation facilities in developing countries. 


\section{Article 10}

\section{Sustainable Use of Components of Biological Dipersity}

Each Contracting Party shall, as far as possible and as appropriate:

(a) Integrate consideration of the conservation and sustainable use of biological resources into national decision-making;

(b) Adopt measures relating to the use of biological resources to avoid or minimize adverse impacts on biological diversity;

(c) Protect and encourage customary use of biological resources in accordance with traditional cultural practices that are compatible with conservation or sustainable use requirements;

(d) Support local populations to develop and implement remedial action in degraded areas where biological diversity has been reduced; and

(e) Encourage cooperation between its governmental authorities and its private sector in developing methods for sustainable use of biological resources.

\section{Article 11}

\section{Incentipe Measures}

Each Contracting Party shall, as far as possible and as appropriate, adopt economically and socially sound measures that act as incentives for the conservations and sustainable use of components of biological diversity.

\section{Article 12}

\section{Research and Training}

The Contracting Parties, taking into account the special needs of developing contries, shall:

(a) Establish and maintain programmes for scientificand technical education and training in measures for the identification, conservation and sustainable use of biological diversity and its components and provide support for such education and training for the specificneeds of developing countries;

(b) Promote and encourage research which contributes to the conservation and sustainable use of biological diversity, 
particularly in developing countries, inter alia, in accordance with decisions of the Conference of the Parties taken in consequence of recommendations of the Subsidiary Body on Scientific, Technical and Thechnological Advice; and

(c) In keeping with the provisions of Articles 16, 18 and 20, promote and cooperate in the use of scientific advances in biological diversity research in developing methods for conservation and sustainable use of biological resources.

\section{Article 13}

\section{Public Education and Awareness}

The Contratcting Parties shall:

(a) Promote and encourage understanding of the importance of, and the measures required for, the conservation of biological diversity, as well as its propagation through media, and the inclusion of these topics in educational programmes; and

(b) Cooperate, as appropriate, with other States and international organizations in developing educational and public awareness programmes, with respect to conservation and sustainable use of biological diversity.

\section{Article 14}

\section{Impact Assessment and Minimizing Adverse Impact} shall:

1. Each Contracting Party, as far as possible and as appropriate,

(a) Introduce appropriate procedures requiring environmental impact assessment of its proposed projects that are likely to have significant adverse effects on biological diversity with a view to avoiding or minimizing such effects and, where appropriate, allow for public participation in such procedures;

(b) Introduce appropriate arrangements to ensure that the environmental consequences of its programmes and policies that are likely to have significant adverse impacts on biological diversity are duly taken into account;

(c) Promote, on the basis of reciprocity, notification, exchange of information and consultation on activities under their jurisdiction or control which are likely to significantly affect adversely the biological diversity of other States or areas 
beyond the limits of national jurisdiction, by encouraging the conclusion of bilateral, regional or multilateral arrrangements, as appropriate;

(d) In the case of imminent or grave danger or damage, originating under its jurisdiction or control, to biological diversity within the area under jurisdiction of other States or in areas beyond the limits of national jurisdiction, notify immediately the potencially affect States or such danger or damage, as well as initiate action to prevent or minimize such danger or damage; and

(e) Promote national arrangements for emergency responses to activities or events, wheter caused naturally or otherwise, wich present a grave and imminent danger to biological diversity and encourage international cooperation to suplement such national efforts and, where appropriate and agreed by the States or regional economic integration organizations concerned, to establish joint contingency plans.

2. The Conference of the Parties shall examine, on the basis of studies to be carried out, the issue of liability and redress, including restoration and compensation, for damage to biological diversity, except where such liability is a purely internal matter.

\section{Article 15 \\ Access to Genetic Resources}

1. Recognizing the sovereign rights of States over their natural resources, the authority to determine access to genetic resources rests with the national governments and is subject to national legislation.

2. Each Contracting Party shall endeavor to create conditions to facilitate access to geneticresources for environmentally sound uses by other Contracting Parties and not to impose restrictions that run counter to the objectives of this Convention.

3. For the purpose of this Convention, the genetic resources being provided by a Contracting Party, as referred to in this Article and Articles 16 and 19, are only those that are provided by Contracting Parties that are countries of origin of such resources or by the Parties that have acquired the genetic resources in accordance with this Convention.

4. Access, where granted, shall be on mutually agreed terms and subject to the provisions of this Article. 
5. Access to genetic resources shall be subject to prior informed consent of the Contracting Party providing such resources, unless otherwise determined by that Party.

6. Each Contracting Party shall endeavour to develop and carry out scientificresearch based on geneticresources provided by other Contracting Parties with the full participation of, and where possible in, such Contracting Parties.

7. Each Contracting Party shall take legislative, administrative or policy measures, as appropriate, and in accordance with Articles 16 and 19 and, where necessary, through the financial mechanism established by Articles 20 and 21 with the aim of sharing in a fair and equitable way the results of research and development and the benefits arising from the commercial and other utilization of genetic resources with the Contracting Party providing such resources. Such sharing shall be upon mutually agreed terms.

\section{Article 16}

\section{Access to and Transfer of Technology}

1. Each Contracting Party, recognizing that technology includes biotechnology, and that both access to and transfer of thechnology among Contracting Parties are essential elements for the attainment of the objectives of this Convention, undertakes subject to the provisions of this Article to provide and/or facilitate access for and transfer to other Contracting Parties of technologies that are relevant to the conservation and sustainable use of biological diversity or make use of genetic resources and do not cause signficant damage to the enviroment.

2. Access to and transfer of technology referred to in paragraph 1 above to developing countries shall be provided and/or facilitated under fair and most favourable terms, including on concessional and preferential terms where mutually agreed, and, where necessary, in accordance with the financial mechanism established by Articles 20 and 21. In the case of technology subject to patents and other intellectual property rights, such access and transfer shall be provided on terms which recognize and are consistent with the adequate and effective protection of intellectual property rights. The application of this paragraph shall be consistente with paragraphs 3,4 and 5 below.

3. Each Contracting Party shall take legislative, administrative or policy measures, as appropriate, with the aim that Contracting Parties, in particular those that are developing countries, wich provide geneticresources are provided access to and transfer of technology which makes use of those resources, on mutually agreed terms, including 
technology protected by patents and other intellectual property rights, where necessary, through the provisions of Articles 20 and 21 and in accordance with international law and consistent with paragraphs 4 and 5 below.

4. Each Contracting Party shall take legislative, administrative or policy measures, as appropriate, with the aim that the private sector facilitates access to, joint development and transfer of technology referred to in paragraph 1 above for the benefit of both governmental institutions and the private sector of developing countries and in this regard shall abide by the obligations included in paragraph 1, 2 and 3 above.

5. The Contracting Parties, recognizing that patents and other intellectual property rights may have an influence on the implementation of this Convention, shall cooperate in this regard subject to national legislation and international law in order to ensure that such rights are supportive of and do not run counter to its objectives.

\section{Article 17}

\section{Exchange of Information}

1. The Contracting Parties shall facilitate the exchange of information, from all publicly available sources, relevant to the conservation and sustainable use of biological diversity, taking into account the special needs of developing countries.

2. Such exchange of information shall include exchange of results of technical, scientific and socio-economicresearch, as well as information on training and surveying programmes, specialized knowledge, indigenous and traditional knowledge as such and in combination with the technologies referred to in Article 16, paragraph 1. It shall also, where feasible, include repatriation of information.

\section{Article 18}

\section{Technical and Scientific Cooperation}

1. The Contracting Parties shall promote international technical and scientificcooperation in the field of conservation and sustainable use of biological diversity, where necessary, through the appropriate international and nacional institutions.

2. Each Contracting Party shall promote technical and scientific cooperation with other Contracting Parties, in particular developing countries, in implementing this Convention, inter alia, through the 
development and implementation of national policies. In promoting such cooperation, special attention should be given to the development and strengthening of national capabilities, by means of human resources development and institution building.

3. The Conference of the Parties, at its first meeting, shall determine how to establish a clearing-house mechanism to promote and facilitate technical and scientific cooperation.

4. The Contracting Parties shall, in accordance with national legislation and policies, encourage and develop methods of cooperation for the development and use of technologies, including indigenous and traditional technologies, in pursuance of the objectives of this Convention. For this purpose, the Contracting Parties shall also promote cooperation in the training of personnel and exchange of experts.

5. The Contracting Parties shall, subject to mutual agreement, promote the establishment of joint research programmes and joint ventures for the development of technologies relevant to the objectives of this Convention.

\section{Article 19}

\section{Handling of Biotechnology and Distribution of its Benefits}

1. Each Contracting Party shall take legislative, administrative or policy measures, as appropriate, to provide for the effetive participation in biotechnological research activities by those Contracting Parties, especially developing countries, which provide the geneticresources for such research, and where feasible in such Contracting Parties.

2. Each Contraction Party shall take all practicable measures to promote and advance priority access on a fair and equitable basis by Contracting Parties, especially developing countries, to the results and benefits arising from biotechnologies based upon genetic resources provided by those Contractin Parties. Such access shall be on mutually agreed terms.

3. The Parties shall consider the need for and modalities of a protocol setting out appropriate procedures, including, in particular, advance informed agreement, in the field of the safe transfer, handling and use of any living modified organism resulting from biotechnology that may have adverse effect on the conservation and sustainable use of biological diversity.

4. Each Contracting Paty shall, directly or by requiring any natural or legal person under its jurisdiction providing the organisms referred to in paragraph 3 above, provide any available information about the use 
and safety regulations required by that Contracting Party in handling such organisms, as well as any available information on the potential adverse impact of the specific organisms concerned to the Contracting Party into which those organisms are to be introduced.

\section{Article 20}

\section{Financial Resources}

1. Each Contracting Party undertakes to provide, in accordance with its capabilities, financial support and incentives in respect of those national activities which are intended to achieve the objectives of this Convention, in accordance with its national plans, priorities and programmes.

2. The developed country Parties shall provide new and additional financial resources to enable developing country Parties to meet the agreed full incremental costs to them of implementing measures which fulfill the obligations of this Convention and to benefit from its provisions and which costs are agreed between a developing country Party and the institutional structure referred to in Article 21, in accordance with policy, strategy, programme priorities and eligibility criteria and an indicative list of incremental costs established by the Conference of the Parties. Other Parties, including countries undergoing the process of transition to a market economy, may voluntarily assume the obligations of the developed country Parties. For the purpose of this Article, The Conference of the Parties, shall at its first meeting establish a list of developed country Parties and other Parties which voluntarily assume the obligations of the developed country Parties. The Conference of the Parties shall periodically review and if necessary amend the list. Contributions from other contries and sources on a voluntary basis would also be encouraged. The implementation of these commitments shall take into account the need for adequacy, predictability and timely flow of funds and the importance of burden-sharing among the contributing Parties included in the list.

3. The developed country Parties may also provide, and developing country Parties avail themselves of, financial resources related to the implementation of this Convention through bilateral, regional and other multilateral channels.

4. The extent to which developing country Parties will effectively implement their commitments under this Convention will depend on the effective implementation by developed country Parties of their commitments under this Convention related to financial resources and transfer of technology and will take fully into account the fact that 
economic and social development and eradication of poverty are the first and overriding priorities of the developing country Parties.

5. The Parties shall take full account of the specific needs and special situation of least developed countries in their actions with regard to funding and transfer of technology.

6. The Contracting Parties shall also take into consideration the special conditions resulting from the dependence on, distribution and location of, biological diversity within developing country Parties, in particular small island States.

7. Consideration shall also be given to the special situation of developing countries, including those that are most environmentally vulnerable, such as those with arid and semi-arid zones, coastal and mountainous areas.

Article 21

\section{Financial Mechanism}

1. There shall be a mechanism for the provision of financial resources to developing country Parties for purposes of this Convention on a grant or concessional basis the essential elements of which are described in this Article. The mechanism shall function under the authority and guidance of, and be accountable to, the Conference of the Parties for purposes of this Convention. The operations of the mechanism shall be carried out by such institutional structure as may be decided upon by the Conference of the Parties at its first meeting. For purposes of this Convention, the Conference of the Parties shall determine the policy, strategy, programme priorities and eligibility criteria relating to the access to and utilization of such resources. The contributions shall be such as to take into account the need for predictability, adequacy and timely flow of funds referred to in Article 20 in accordance with the amount of resources needed to be decided periodically by the Conference of the Parties and the importance of burden-sharing among the contributing Parties included in the list referred to in Article 20, paragraph 2. Voluntary contributions may also be made by developed country Parties and by other countries and sources. The mechanism shall operate within a democratic and transparent system of governance.

2. Pursuant to the objectives of this Convention, the Conference of the Parties shall at its first meeting determine the policy, strategy and programme priorities, as well as detailed criteria and guidelines for eligibility for access to and utilization of the financial resources including monitoring and evaluation on a regular basis of such utilization. The 
Conference of the Parties shall decide on the arrangements to give effect to paragraph 1 above after consultation with the institutional structure entrusted wich the operation of the financial mechanism.

3. The Conference of the parties shall review the effectiveness of the mechanism established under this Article, including the criteria and guidelines referred to in paragraph 2 above, not less than two years after the entry into force of this Convention and thereafter on a regular basis. Based on such review, it shall take appropriate action to improve the effectiveness of the mechanism if necessary.

4. The Contracting Parties shall consider strengthening existing financial institutions to provide financial resources for the conservation and sustainable use of biological diversity.

\section{Article 22}

\section{Relationship with Other International Conpentions}

1.The provisions of this Convention shall not affect the rights and obligations of any Contracting Party deriving from any existing internacional agreement, except where the exercise of those rights and obligations would cause a serious damage or threat to biological diversity.

2. Contracting Parties shall implement this Convention with respect to the marine environment consistently with the rights and obligations of States under the law of the sea.

\section{Article 23}

\section{Conference of the Parties}

1. A Conference of the Parties is hereby established. The first meeting of the Conference of the Parties shall be convened by the Executive Director of the United Nations Environment Programme not later than one year after the entry into force of this Convention. Thereafter, ordinary meetings of the Conference of the Parties shall be held at regular intervals to be determined by the Conference at its first meeting.

2. Extraordinary meetings of the Conference of the Parties shall be held at such other times as may be deemed necessary by the Conference, or at the written request of any Party, provided that, within six months of the request being communicated to them by the Secretariat, it is supported by at least one third of the Parties. 
3. The Conference of the Parties shall by consensus agree upon and adopt rules of procedure for itself and for any subsidiary body it may establish, as well as financial rules governing the funding of the Secretariat. At each ordinary meeting, it shall adopt a budget for the financial period until the next ordinary meeting.

4. The Conference of the Parties shall keep under review the implementation of this Convention, and, for this purpose, shall:

(a) Establish the form and the intervals for transmitting the information to be submitted in accordance with Article 26 and consider such information as well as reports submitted by any subsidiary body;

(b) Review scientific, technical and technological advice on biological diversity provided in accordance with Article 25;

(c) Consider and adopt, as required, protocols in accordance with Article 28;

(d) Consider and adopt, as required, in accordance with Articles 29 and 30, amendments to this Convention and its annexes;

(e) Consider amendments to any protocol, as well as to any annexes thereto, and, if so decided, recommend their adoption to the parties to the protocol concerned;

(f) Consider and adopt, as required, in accordance with Article 30, additional annexes to this Convention;

(g) Establish such subsidiary bodies, particularly to provide scientificand technical advice, as are deemed necessary for the implementation of this Convention;

(h) Contact, through the Secretariat, the executive bodies of conventions dealing withmatters covered by this Convention with a view to establishing appropriate forms of cooperation with them; and

(i) Consider and undertake any additional action that may be required for the achievement of the purposes of this Convention in the light of experience gained in its operation.

5. The United Nations, its speciliazed agencies and the Internacional Atomic Energy Agency, as well as any State not Party to this Convencion, may be represented as observers at meetings of the Conference of the Parties. Any other body or agency, wheter governmental or non-governmental, qualified in fields relating to conservation and sustainable use of biological diversity, which has informed the Secretariat of its wish to be represented as an observer at a meeting of the Conference of the Parties, may be admitted unless at least one third of the Parties present object. The admission and participation 
of observers shall be subject to the rules of procedure adopted by the Conference of the Parties.

\section{Article 24}

\section{Secretariat}

1. A secretariat is hereby established. Its functions shall be:

(a) To arrange for and service meetings of the Conference of the Parties provided for in Article 23;

(b) To performe the functions assigned to it by any protocol;

(c) To prepare reports on the execution of its functions under this Convention and present them to the Conference of the Parties;

(d) To coordinate with other relevant international bodies and, in particular to enter into such administratitive and contractual arrangements as may be required for the effective discharge of its functions; and

(e) To perform such other functions as may be determined by the Conference of the Parties.

2. At its first ordinary meeting, the Conference of the Parties shall designate the secretariat from amongst those existing competent international organizations which have signified their willingness to carry out the secretariat functions under this Convention.

\section{Article 25}

\section{Subsidiary Body on Scientific,}

\section{Technical and Technological Adpice}

1. A subsidiary body for the provision of scientific, technical and technological advice is hereby established to provide the Conference of the Parties and, as appropriate, its other subsidiary bodies with timely advice relating to the implementation of this Convention. This body shall be open to participation by all Parties and shall be multidisciplinary. It shall comprise government representatives competent in the relevant field of expertise. It shall report regularly to the Conference of the Parties on all aspects of its work.

2. Under the authority of and in accordance with guidelines laid down by the Conference of the Parties, and upon its request, this body shall: 
(a) Provide scientific and technical assessments of the status of biological diversity;

(b) Prepare scientific and technical assessments, of the effects of types of measures taken in accordance with the provisions of this Convention;

(c) Identify innovative, efficient and state-of-the-art technologies and know-how relating to the conservation and sustainable use of biological diversity and advise on the ways and means of promoting development and/or transferring such technologies;

(d) Provide advice on scientific programmes and international cooperation in research and development related to conservation and sustainable use of biological diversity; and

(e) Respond to scientific, technical, technological and methodological questions that the Conference of the Parties and its subsidiary bodies may put to the body.

3. The functions, terms of reference, organization and operation of this body may be further elaborated by the Conference of the Parties.

\section{Article 26}

\section{Reports}

Each Contracting Party shall, at intervals to be determined by the Conference of the Parties, present to the Conference of the Parties, reports on measures which it has taken for the implementation of the provisions of this Convention and their effectiveness in meeting the objectives of this convention.

\section{Article 27}

\section{Settlement of Disputes}

1. In the event of a dispute between Contracting Parties concerning the Interpretation or application of this Convention, the parties concerned shall seek solution by negotiation.

2 . If the parties concerned cannot reach agreement by negotiation, they may jointly seek the good offices of, or request mediation by, a third party.

3. When ratifying, accepting, approving or acceding to this Convention, or at any time thereafter, a State or regional economic integratin organization may declare in writing to the Depositary that for 
a dispute not resolved in accordance with paragraph 1 or paragraph 2 above, it accepts one or both of the following means of dispute settlement as compulsory:

(a) Arbitration in accordance with the procedure laid down in Part 1 of Annex II;

(b) Submission of the dispute to the International Court of Justice.

4. If the parties to the dispute have not, in accordance with paragraph 3 above, accepted the same or any procedure, the dispute shall be submitted to conciliation in accordance with Part 2 of Annex II unless the parties otherwise agree.

5. The provisions of this Article shall apply with respect to any protocol except as otherwise provided in the protocol concerned.

\section{Article 28}

\section{Adoption of Protocols}

1. The Contracting Parties shall cooperate in the formulation and adoption of protocols to this Convention. Parties.

2. Protocols shall be adopted at a meeting of the Conference of the

3. The text of any proposed protocol shall be communicated to the Contracting Parties by the Secretariat at least six months before such a meeting.

\section{Article 29}

\section{Amendment of the Convention or Protocols}

1. Amendments to this Convention may be proposed by any Contracting Party. Amendments to any protocol may be proposed by any Party to that protocol.

2. Amendments to this Convention shall be adopted at a meeting of the Conference of the Parties. Amendments to any protocol shall be adopted at a meeting of the Parties to the Protocol in question. The text of any proposed amendment to this Convention or to any protocol, except as may otherwise be provided in such protocol, shall be communicated to the Parties to the instrument in question by the secretariat at least six months before the meeting at which it is proposed for adoption. The secretariat shall also communicate proposed amendments to the signatories to this Convention for information. 
3. The Parties shall make every effort to reach agreement on any proposed amendment to this Convention or to any protocol by consensus. If all efforts at consensus have been exhausted, and no agreement reached, the amendment shall as a last resort to be adopted by a two-third majority vote of the Parties to the instrument in question present and voting at the meeting, and shall be submitted by the Depositary to all Parties for ratification, acceptance or approval.

4. Ratification, acceptance or approval of amendments shall be notified to the Depositary in writing. Amendments adopted in accordance with paragraph 3 above shall enter into force among Parties having accepted them on the ninetieth day after the deposit of instruments of ratification, acceptance or approval by at least two thirds of the Contracting Parties to this Convention or of the Parties to the protocol concerned, except as may otherwise be provided in such protocol. Thereafter the amendments shall enter into force for any other Party on the ninetieth day after the Party deposits its instrument of ratification, acceptance or approval of the amendments.

5. For the purposes of this Article, "Parties present and voting" means Parties present and casting an affirmative or negative vote.

\section{Article 30 \\ Adoption and Amendment of Annexes}

1. The annexes to this Convention or to any protocol shall form an integral part of the Convention or of such protocol, as the case may be, and, unless expressely provided otherwise, a reference to this Convention or its protocols constitutes at the name time a reference to any annexes thereto. Such annexes shall be restricted to procedural, scientific, technical and administrative matters.

2. Except as may be otherwise provided in any protocol with respect to its annexes, the following procedure shall apply to the proposal, adoption and entry into force of addtional annexes to this Convention or of annexes to any protocol:

(a) Annexes to this Convention or to any protocol shall be proposed and adopted according to the procedure laid down in Article 29;

(b) Any Party that is unable to approve an additional annex to this Convention or an annex to any protocol to which it is Party shall so notify the Depositary, in writing, whithin one year from the date of the communication of the adoption by the Depositary. The Depositary shall without delay notify all 
Parties of any such notification received. a Party may at any time withdraw a previous declaration of objection and the annexes shall thereupon enter into force for that Party subject to subparagraph (c) below;

(c) On the expiry of one year from the date of the communication of the adoption by the Depositary, the annex shall enter into force for all Parties to this Convention or to any protocol concerned which have not submitted a notification in accordance with the provisions of subparagraph (b) above.

3. The proposal, adoption and entry into force of amendments to annexes to this Convention or to any protocol shall be subject to the same procedure as for the proposal, adoption and entry into force of annexes to the Convention or annexes to any protocol.

4. If an additional annex or an amendment to an annex is related to an amendment to this Convention or to any protocol, the additional annex or amendment shall not enter into force until such time as the amendment to the Convention or to the protocol concerned enters into force.

\section{Article 31}

\section{Right to Vote}

1. Except as provided for in paragraph 2 bellow, each Contracting Party to this Convention or to any protocol shall have one vote.

2. Regional economic integration organizations, in matters within their competence, shall exercise their right to vote with a number of votes equal to the number of their member States which are Contracting Parties to this Convention or the relevant protocol. Such organizations shall not exercise their right to vote if their member States exercise theirs, and vice versa.

\section{Article 32}

\section{Relationship Between this Convention and its Protocols}

1. A State or a regional economicintegration organization may not become a Party to a protocol unless it is, or become at the same time, a Contracting Party to this Convention.

2. Decisions under any protocol shall be taken only by the Parties to the protocol concerned. Any Contracting Party that has not ratified, accepted or approved a protocol may participate as an observer in any meeting of the parties to that protocol. 


\section{Article 33}

\section{Signature}

This Convention shall be open for signature at Rio de Janeiro by all States and any regional economicintegration organization from 5 June 1992 until 14 June 1992, and at the United Nations Headquartes in New York from 15 June 1992 to 4 June 1993.

\section{Article 34}

\section{Ratification, Acceptance or Appropal}

1. This Convention and any protocol shall be subject to ratification, acceptance or approval by States and by regional economic integration organizations. Instruments of ratification, acceptance or approval shall be deposited with the Depositary.

2. Any organization referred to in paragraph 1 above wich becomes a Contracting Party to this Convention or any protocol without any of its member States being a Contracting Party shall be bound by all the obligations under the Convention or the protocol, as the case may be. In the case or such organizagions, one or more of whose member States is a Contracting Party to this Convention or relevant protocol, the organization and its member States shall decide on their respective responsabilities for the performance of their obligations under the Convention or protocol, as the case may be. In such cases, the organization and the member States shall not be entitled to exercise rights under the Convention or relevant protocol concurrently.

3. In their instruments of ratification, acceptance or approval, the organizations referred to in paragraph 1 above shall declare the extent of their competence with respect to the matters governed by the Convention or the relevant protocol. These organizations shall also inform the Depositary of any relevant modification in the extent of their competence.

\section{Article 35}

\section{Accession}

1. This Convention and any protocol shall be open for accession by States and by regional economicintegration organizations from the date on wich the Convention or the protocol concerned is closed for signature. The instruments of accession shall be deposited with the Depositary. 
2. In their instruments of accession, the organizations rcferred to in paragraph 1 above shall declare the extent of their competence with respect to the matters governed by the Convention or the relevant protocol. These organizations shall also inform the Depositary of any relevant modification in the extend of their competence.

3. The provisions of Article 34, paragraph 2, shall apply to regional economic integration organizations which accede to this Convention or any protocol.

\section{Article 36}

\section{Entry Into Force}

1. This Convention shall enter into force on the ninetieth day after the date of deposit of the thirtieth instrument of ratification, acceptance, approval or accession.

2. Any protocol shall enter into force on the ninetieth day after the date of deposit of the number of instruments of ratification, acceptance, approval or accession, specified in that protocol, has been deposited.

3. For each Contracting Party which ratifies, accepts or approves this Convention or accedes thereto after the deposit of the thirtieth instrument of ratification, acceptance, approval or accession, it shall enter into force on the ninetieth day after the date of deposit by such Contracting Party of its instrument of ratification, acceptance, approval or accession.

4. Any protocol, except as otherwise provided in such protocol, shall enter into force for a Contracting Party that ratifies, accepts or approves that protocol or accedes thereto after its entry into force pursuant to paragraph 2 above, on the ninetieth day after the date on which that Contracting Party deposits its instrument of ratification, acceptance, approval or accession, or on the date on wich this Convention enters into force that Contracting Party, whichever shall be the later.

5. For the purposes of paragraphs 1 and 2 above, any instrument deposited by a regional economic integration organization shall not be counted as additional to those deposited by member States or such organization.

\section{Article 37}

\section{Reserpations}

No reservations may be made to this Convention. 


\section{Article 38}

\section{Withdrawals}

1. At any time after two years from the date on which this Convention has entered into force for a Contracting Party, that Contracting Party may withdraw from the Convention by giving written notification to the Depositary.

2. Any such withdrawal shall take place upon expiry of one year after the date of its receipt by the Depositary, or on such later date as may be specified in the notification of the withdrawal.

3. Any Contracting Party which withdraws from this Convention shall be considered as also having withdrawn from any protocol to which it is party.

\section{Article 39}

\section{Financial Interim Arrangements}

Provided that it has been fully restructured in accordance with the requirements of Article 21, the Global Environment Facility of the United Nations Development Programme, the United Nations Environment Programme and the International Bank for Reconstruction and Development shall be the institutional structure referred to in Article 21 on an interim basis, for the period between the entry into force of this Convention and the first meeting of the Conference of the Parties or until the Conference of the Parties decides which institutional structure will be designated in accordance with Article 21.

\section{Article 40 \\ Secretariat Interim Arrangements}

The secretariat to be provided by the Executive Director of the United Nations Environment Programme shall be secretariat referred to in Article 24, paragraph 2, on an interim basis for the period between the entry into force of this Convention and the first meeting of the Conference of the Parties.

\section{Article 41}

\section{Depositary}

The Secretary-General of the United Nations shall assume the functions of Depositary of this Convention and any protocols. 


\section{Article 42}

\section{Autbentic Texts}

The original of this Convention, of which the Arabic, Chinese, English, French, Russian and Spanish texts are equally authentic, shall be deposited with the Secretary-General of the United Nations.

IN WITNESS WHEREOF the undersigned, being duly authorized to that effect, have signed this Convention.

Done at Rio de Janeiro on this fifth day of June, one thousand nine hundred and ninety-two.

\section{Annex I \\ Identification and Monitoring}

1. Ecosystems and habitats: containing high diversity, large numbers of endemicor threatened species, or wilderness; required by migratory species; of social, economic, cultural or scientific importance; or, which are representative, unique or associated with key evolutionary or other biological processes;

2. Species and communities which are: threatened; wild relatives of domesticated or cultivated species; of medicinal, agricultural or other economic value; or social, scientific or cultural importance; or importance for research into the conservation and sustainable use of biological diversity, such as indicator species; and

3. Described genomes and genes of social, scientific or economic importance.

\section{Annex II}

\section{Part 1}

\section{Arbitration}

\section{Article 1}

The claimant party shall notify the secretariat that the parties are referring a dispute to arbitration pursuant to Article 27. The notification shall state the subject-matter of arbitration and include, in particular, the articles of the Convention or the protocol, the interpretation or application of which are at issue. If the parties do not agree on the 
subject matter of the dispute before the President of the tribunal is designated, the arbitral tribunal shall determine the subject matter. The secretariat shall forward the information thus received to all Contracting Parties to this Convention or to the protocol concerned.

\section{Article 2}

1. In disputes between two parties, the arbitral tribunal shall consist of three members. Each of the parties to the dispute shall appoint an arbitrator and the two arbitrators so appointed shall designate by common agreement the third arbitrator who shall be the President of the tribunal. The latter shall not be a national of one of the parties to the dispute, nor have his or her usual place of residence in the territory of one of these parties, nor be employed by any of them, nor have dealt with the case in any other capacity.

2. In disputes between more than two parties, parties in the same interest shall appoint one arbitrator jointly by agreement.

3. Any vacancy shall be filled in the manner prescribed for the initial appointment.

\section{Article 3}

1. If the President of the arbitral tribunal has not been designated within two months of the appointment of the second arbitrator, the Secretary-General of the United Nations shall, at the request of a party, designate the President within a further two-month period.

2. If one of the parties to the dispute does not appoint an arbitrator within two months of receipt of the request, the other party may inform the Secretary-General who shall make the designation within a further two-month period.

\section{Article 4}

The arbitral tribunal shall render its decisions in accordance with the provisions of this Convention, any protocols concerned, and international law.

\section{Article 5}

Unless the parties to the dispute otherwise agree, the arbitral tribunal shall determine its own rules of procedure. 


\section{Article 6}

The arbitral tribunal may, at the request of one of the parties recommend essential interim measures of protection.

\section{Article 7}

The parties to the dispute shall facilitate the work of the arbitral tribunal and, in particular, using all means at their disposal, shall:

(a) Provide it with all relevant documents, information and facilities; and

(b) Enable it, when necessary, to call witnesses or experts and receive their evidence.

\section{Article 8}

The parties and the arbitrators are under an obligation to protect the confidentiality of any information they receive in confidence during the proceedings of the arbitral tribunal.

\section{Article 9}

Unless the arbitral tribunal determines otherwise because of the particular circunstances of the case, the costs of the tribunal shall be borne by the parties to the dispute in equal shares. The tribunal shall keep a record of all its costs, and shall furnish a final statenent thereof to the parties.

\section{Article 10}

Any Contracting Party that has an interest of a legal nature in the subject-matter of the dispute which may be affected by the decision in the case, may intervene in the proceedings with the consent of the tribunal.

\section{Article 11}

The tribunal may hear and determine counterclaims arising directly out of the subject-matter of the dispute.

\section{Article 12}

Decisions both on procedure and substance of the arbitral tribunal shall be taken by a majority vote of its members. 


\section{Article 13}

If one of the parties to the dispute does not appear before the arbitral tribunal or fails to defend its case, the other party may request the tribunal to continue the proceedings and to make its award. Absence of a party or a failure of a party to defend its case shall not constitute a bar to the proceedings. Before rendering its final decision, the arbitral tribunal must satisfy itself that the claim is well founded in fact and law.

\section{Article 14}

The tribunal shall render its final decision within five months of the date on which it is fully constituted unless it finds it necessary to extend the time-limit for a period which should not exceed five more months.

\section{Article 15}

The final decision of the arbitral tribunal shall be confined to the subject-matter of the dispute and shall state the reasons on which it is based. It shall countain the names of the members who have participated and the date of the final decision. Any member of the tribunal may attach a separate or dissenting opinion to the final decision.

\section{Article 16}

The award shall be binding on the parties to the dispute. It shall be without appeal unless the parties to the dispute have agreed in advance to an appellate procedure.

\section{Article 17}

Any controversy which may arise between the parties to the dispute as regards the interpretation or manner of implementation of the final decision may be submitted by either party for decision to the arbitral tribunal which rendered it.

\section{Part}

\section{Conciliation}

\section{Article 1}

A conciliation commission shall be created upon the request of one of the parties to the dispute. The commission shall, unless the parties 
otherwise agree, be composed of five members, two appointed by each Party concerned and a President chosen jointly by those members.

\section{Article 2}

In disputes between more than two parties, parties in the same interest shall appoint their members of the commission jointly by agreement. Where two or more parties have separate interests or there is a disagreement as to whether they are of the same interest, they shall appoint their members separately.

\section{Article 3}

If any appointments by the parties are not made within two months of the date of the request to create a conciliation commission, the Secretary-General of the United Nations shall, if asked to do so by the party that made the request, make those appointments within a further two-month period.

\section{Article 4}

If a President of the conciliation commission has not been chosen within two months of the last of the members of the commission being appointed, the Secretary-General of the United Nations shall, if asked to do so by a party, designate a President within a further two-month period.

\section{Article 5}

The conciliation commission shall take its decisions by majority vote of its members. It shall, unless the parties to the dispute otherwise agree, determine its own procedure. It shall render a proposal for resolution of the dispute, which the parties shall consider in good faith.

\section{Article 6}

A disagreement as to whether the conciliation commission has competence shall be decided by the commission. 